\title{
Flavin Containing Monooxygenases and Metabolism of Xenobiotics
}

\author{
Flavin İçeren Monooksijenazlar ve Ksenobiyotiklerin Metabolizması
}

\author{
Rahman BAŞARAN, Benay CAN EKE* \\ Ankara University, Faculty of Pharmacy, Department of Pharmaceutical Toxicology, Ankara, Turkey
}

\begin{abstract}
This review summarizes recent information concerning the pharmacological and toxicological significance of the flavin-containing monooxygenases (FMOs). FMOs are a family of microsomal enzymes involving in the oxygenation of certain xenobiotics and drugs containing nucleophilic heteroatoms. The activities of FMOs in drug metabolism and their relationships with diseases are the areas of research requiring further exploration. Future studies on FMOs may provide considerable information about the pathophysiology of diseases and the information related to this enzyme family may be important for drug designs in future.
\end{abstract}

Key words: Flavin monooxygenase, microsomal enzymes, phase 1 reactions

öz

Bu derlemede flavin-içeren monooksijenazların (FMO) farmakolojik ve toksikolojik önemi ile ilgili güncel bilgiler özetlenmiştir. FMO'lar nükleofilik hetereatom içeren ksenobiyotiklerin ve ilaçların oksidasyonuna katılan mikrozomal bir enzim ailesidir. FMO'ların ilaç metabolizmasındaki etkinlikleri ve hastalıklarla olan ilişkileri, daha fazla araştııılması gereken alanlardır. FMO'lar üzerine yapılacak olan araştırmalar hastalıkların patofizyolojisi hakkında önemli bilgiler sağlayabilir ve bu enzim ailesi ile ilgili bilgiler gelecekte, ilaç tasarımları için önemli olabilir.

Anahtar kelimeler: Flavin monooksijenazlar, mikrozomal enzimler, faz 1 reaksiyonları

\section{INTRODUCTION}

All organisms are exposed unavoidably to chemicals (or xenobiotics such as drugs, pesticides, industrial chemicals, pollutants) with increasing industrialization and changing living conditions. Water-soluble of these chemicals are eliminated via the kidneys directly, whereas some chemical compounds are not suitable for renal excretion and lipophilic chemicals are converted to more hydrophilic forms by biotransformation. Increasing hydrophilicity of chemicals makes their excretion more efficient. Enzymes in catalyzing biotransformation reactions are generally divided into two groups, called phase 1 and phase 2. Cytochrome P450 (CYP450) and flavin-containing monooxygenases (FMOs) are the most important enzymes of phase 1 reactions.

FMO enzymes are believed to protect organisms against xenobiotics in early environment such as CYP450 enzyme family. ${ }^{2}$ Mammalian FMO enzymes from pig liver microsomes were first described in the 1970s by Ziegler and Poulsen. ${ }^{3}$
Biochemical properties of FMOs were described largely by Ziegler and Poulsen. ${ }^{3}$ As a result, for some time, this enzyme was known as Ziegler's enzyme. In the 1980s, pulmonary and hepatic forms of FMOs were exhibited distinct differences with regard to enzyme properties and substrate specificity. ${ }^{4}$ Researchers have been knowledged about the structural, functional and regulatory aspects of FMOs since $1990 .^{5}$ Despite this progress, knowledge about FMOs is still insufficient.

\section{Catalytic Mechanism of flavin-containing monooxygenases}

FMO is a flavoprotein containing a single flavin adenine dinucleotide (FAD), as a prosthetic group. The microsomal nicotinamide adenine dinucleotide phosphate (NADPH) and molecular oxygen-dependent FMOs catalyze the oxidative metabolism of a wide variety of xenobiotics, including nucleophilic nitrogen-, sulfur-, phosphorous-, and seleniumheteroatoms. FMOs displayed activity toward a broad range of substrates consisting of phosphines, hydrazines, sulfides, selenides, iodide, boron-containing compounds and primary, 
secondary, and tertiary amines. ${ }^{6}$ FMOs are responsible for about $6 \%$ of all the phase 1 reactions, and therefore, about $2.5 \%$ of all metabolic reactions. ${ }^{7,8}$ These enzymes provide an efficient detoxification system for xenobiotics, by converting the lipophilic xenobiotics into polar, oxygenated, and readily excreted metabolites. 6,9

FMOs catalyze the oxidative metabolism clinically important drug, including morphine, cocaine, nicotine, tamoxifen, fluoxetine, methimazole, chlorpromazine, imipramine, benzydamin, itoprid and clozapine; environmental toxins, including phorate, fonofos, aldicarb; endogenous substrates, including triamine, trimethylamine, catecholamines, cysteamine and methionine. ${ }^{10-13}$

FMO catalytic activity is quite different from the catalytic activity of CYP450 enzymes. Unlike CYPs, C (4a) hydroxyperoxide, which is a stable intermadiate, is produced during the catalytic cycle of FMOs. This intermediate product can remain stable for hours at $4^{\circ} \mathrm{C}$ and can be observed as spectral. This product is considered to be the form in which FMO exists in the cell. ${ }^{10,13}$ The catalytic cycle of FMO are shown in Figure 1. In step 1 of FMO catalytic cycle, NADPH cofactor binds to the enzyme and FAD is reduced by two electrons from NADPH. In step 2, the reduced $F A D$ reacts rapidly with molecular oxygen and formation of flavin hydroxy-peroxide. Subsequently, the nucleophilic substrate is coupled with this intermadiate products. One oxygen atom of molecular oxygen which reacts in the second step binds to substrate and the oxidized form of the substrate leaves the cycle. The other oxygen atom incorporated into $\mathrm{H}_{2} \mathrm{O}$ FMO is a monooxygenase. In the final step of FMO catalytic cycle, followed by a slow reaction, $\mathrm{NADP}^{+}$is released from the enzyme. Disintegrated reaction of falcarindiol and released reaction of $\mathrm{NADP}^{+}$are thought to be the rate-limiting steps in the catalytic cycle of FMOs. In either case, substrate binding has no effect on Vmax. ${ }^{13}$

Comparison of flavin-containing monooxygenases and CYP450 These two enzyme families which take part in the oxidization stages of phase 1 reactions resemble each other with respect to needing NADPH and molecular oxygen for catalytic activities,

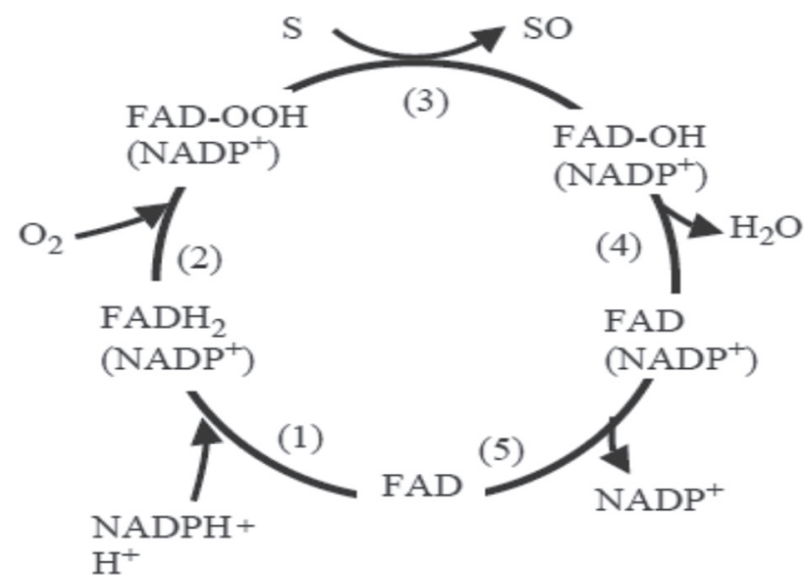

Figure 1. Catalytic cycle of flavin-containing monooxygenases ${ }^{13}$ NADPH: Nicotinamide adenine dinucleotide phosphate, FAD: Flavin adenine dinucleotide adding oxygen to the substrate during the reactions, having similar molecular weights, being localized in the endoplasmic reticulum in the cell, having the highest concentration in the liver and substantial amount in the entry and excretion organs for xenobiotics in the body such as lungs, skin, stomach, intestines and kidneys, and having the similar chemicals as substrates. ${ }^{13}$

In contrast to CYP450 gene family, FMO genes are expressed with less number of genes. ${ }^{14}$ While most of the CYP450 enzymes take part in synthesis and catabolism reactions, the synthesis and catabolism reactions of FMOs are not clear except for the xenobiotic metabolisms. Catalytic cycles of FMOs and CYPs are significantly different from each other. For example, there is no real binding between the FMO and the substrate during the catalytic cycle of the FMO. ${ }^{13}$ Despite using the same substrates, these enzymes usually create different products. In general, FMO enzymes produce less toxic metabolites compared to the CYP enzymes. ${ }^{15}$ There is a specific inhibitor for almost each CYP450 enzyme, but there are no identified mechanism based inhibitors for FMOs. ${ }^{16}$ FMO enzymes are more vulnerable to heat than CYPs and they are active in higher optimal $\mathrm{pHs}^{17}$ Unlike CYPs, FMOs are not easily induced with xenobiotics and do not become inhibited. ${ }^{15}$ Despite not all, but for most drugs and xenobiotics, FMOs most probably have a secondary role compared to CYPs. While it is known that the number of FMOs participating in the drug metabolism is less than that of CYPs, the contribution of FMOs to the metabolism of drugs and other xenobiotics is still not clearly described. ${ }^{13}$

\section{Nomenclature}

It is proposed that the emergence of FMO gene family is due to a sequence of independent gene duplication. Human FMO genes are located in two clusters in chromosome 1. The first cluster is on the long branch of the chromosome 1 (q23-25) and the second cluster lies on the other region of the chromosome 1; however this second region contains pseudogenes. Up to now, a total of 5 FMOs, all of which are active, have been identified in the mammals. ${ }^{18}$ FMOs with sequence similarities of more than $40 \%$ are classified inside the same family such as FMO1, FMO2 etc. ${ }^{19}$ The sequence similarity for the functional human FMO forms (FMO1-FMO5) is in the $52-60 \%$ range. As an exceptional case, there is a sequence similarity of $71 \%$ between FMO3 and FMO6. ${ }^{20,21}$ The translation products of FMO genes have a length of 532-558 amino acids. These products contain highly protected FAD and NADPH regions. ${ }^{22}$ FMOs, which have been named as flavin-mixed functional monooxygenases or Ziegler's enzyme, are now named in accordance with their protein structures and FMO prefix is used in order to indicate the genes.

\section{Localization and expression of flavin-containing monooxygenases}

Among the FMO genes identified for bacteria to humans, the research is mostly concentrated on those for mammals. ${ }^{23}$ The presence of FMO has been shown in most species and tissues mainly in liver, lung, kidney, intestine and brain tissue; and the studies are focused specifically on the liver and kidney where 
xenobiotics are metabolized. In recent years, brain tissue has become prominent in FMO research. The presence of FMO has been detected in the human ${ }^{24}$, monkey ${ }^{25}$, rat $^{26}$, and rabbit ${ }^{27}$ brains; and although low activity is reported for the brain FMOs, it has been pointed out that for specific substrates and regional concentrations, they have an important effect in the metabolism of xenobiotics. ${ }^{28}$ Moreover, despite FMOs existing only in microsomal fractions in the liver, they are also found in the other intracellular fractions in the brain, besides microsomes. ${ }^{29}$ The tissue specific expressions of FMOs are quite diverse between species. Hence studies on the rat brain FMOs are not easily compatible for the understanding of the human brain FMO enzyme activities and expressions. ${ }^{22}$

In some tissues, the FMO concentration is very high. For example, FMOs constitute more than $10 \%$ of the total microsomal proteins in the rabbit lungs. Considering the effect of FMOs on the metabolism, this high concentration is essential in terms of toxicological evaluations. ${ }^{30}$

FMO1 is the most common FMO in adult human kidney. Fetal liver and small intestine expression of FMO1 is approximately by 10-14 times less than the FMO1 expression in the adult kidney. The lung FMO1 expression is approximately $2.8 \%$ of the expression of FMO1 in kidney. The FMO1 expression in the brain is less than 1\% of FMO1 in kidney, and there is suppression for the FMO1 expression in the brain after birth.

FMO2 is the dominant FMO type in the lungs and the FMO2 expression in the kidney is around 7 times less than that of the lung. Liver FMO2 expression is approximately $2 \%$ of the expression of FMO2 in lung. The FMO2 expression in the brain is less than 1\% of that of the lung, and the amount of FMO2 in the brain is approximately the same for all age groups.

FMO3 is the most important FMO type in the liver and the level of $\mathrm{FMO} 3$ in the lungs, kidney, fetal liver and small intestines are $4.5 \%, 3.7 \%, 2.1 \%$ and $1 \%$ of the $\mathrm{FMO} 3$ level in the liver, respectively. The FMO3 expression in the brain is less than $1 \%$ of FMO3 in liver and does not change with age.

FMO4 is most commonly present in the liver and kidneys, and the FMO4 expression in the fetal liver, small intestine and lungs are approximately $10.9 \%, 10.8 \%$ and $7 \%$ of the liver FMO4 expression, respectively. The FMO4 expression in the brain is less than $1 \%$ of that of the liver and does not change with age.

FMO5 is highly abundant in the adult liver and the amount of FMO5 in the fetal liver, small intestine, kidney and lung is $18.8 \%, 12.8 \%, 9.8 \%$ and $4 \%$ of the amount of FMO5 in the liver, respectively. The amount of FMO5 in the brain is less than $1 \%$ of the liver FMO3 amount and does not change with age. ${ }^{22}$ Contrary to the previous studies on the human FMO, it has been reported that the hepatic FMO5 expression is equal to or larger than FMO3 expression, and it is the dominant form of FMO in the adult liver. ${ }^{31}$

\section{Factors affecting flavin-containing monooxygenases}

The results obtained from animal modeling and human studies indicate that FMO can be regulated by physiological factors such as age, gender, pregnancy, hormones, diet. ${ }^{32-35}$ Aside from physiological factors, co-factor supply and external factors that can affect the enzyme also have roles in the regulation of FMO enzymes.

\section{Age}

In populations, the expressions of specific genes change with the age and this in turn makes the understanding of the impact of genes on aging and illnesses more essential. On the other hand, it can be shown that a gene which increases in abundance as the population ages can be protective over the metabolism. For example, it has been shown that among FMO types, human brain FMO1 genes have a different profile. ${ }^{36}$ In a study where the expressions of different FMO expression were investigated and the sample was divided into five groups based on age, it has been reported that the brain FMO1 expression is lower than that of other tissues, that there is a significant difference observed between the prenatal 17-21 week old samples and other three postnatal samples (0-8 months, 1039 years, 40-70 years old), and that the expression of FMO1 in the brain is suppressed after birth. ${ }^{37}$ However, no significant difference has been encountered before and after birth for the cases of other FMO forms aside from FMO1 (FMO2, FMO3, FMO4 and FMO5).

\section{Gender}

The effect of gender on the human FMO function has not been clearly identified. In some of the studies conducted, this factor has been investigated, however with the existing knowledge it does not seem possible to determine the impact of this factor on the FMO function. In a study based on the own accounts of sample individuals, it has been reported that trimethylaminuria caused by FMO3 enzyme deficiency is observed more in woman individuals. ${ }^{38}$ In the study, it has been additionally reported that the reason for this case is the emergence of a temporary trimethylaminuria during menstruation in some women, although not in all women, induced by functional changes in FMO3. ${ }^{39}$

\section{Diet}

The gastrointestinal system naturally functions with the direct intake of food. If nutrition happens through direct infusion to the systemic circulation, some pathophysi-ologic changes occur due to bypassing of processes (e.g. intestinal absorption, etc.) in the system. Enzymes that are active in the xenobiotic metabolism are also affected by these changes. A study shows that in the rats that have been fed intravenously show $25 \%$ decrease in CYP450 content and 40-55\% decrease in the CYP functional activity compared to the rats that have been fed orally. ${ }^{40}$ In another study, it has been revealed that the FMO4 immunoreactivity is increased in rats that have been fed intravenously. ${ }^{34}$

It is known that FMOs, which are one of the enzymes active in xenobiotics metabolism, in general can be affected by diet, and with more research data on the subject, the effect of diet can be more clearly understood. 
The relationship of flavin-containing monooxygenases and diseases

FMO enzymes are highly polymorphic, and this aspect is important on the metabolic events that the enzymes are active in. Polymorphisms in the FMOs can change the enzyme activity. Therefore, the FMOs can be associated with diseases via metabolism of chemicals. The primary disease associated directly with FMO is "Fish Odor Syndrome" (trimethylaminuria). Trimethylamine smells like rotten fish, and it is excreted after being transformed to an odorless $\mathrm{N}$-oxide form in the human liver by FMO3. Some polymorphisms in the $\mathrm{FMO} 3$ gene causes functional loss and malfunctions occur in the trimethylamine metabolism. In patients with this syndrome, especially sweat, urine and breath have the rotten fish odor. ${ }^{13,38}$ There is yet no cure for the syndrome; however, the strength of the odor can be reduced by avoiding certain types of food such as fish, eggs, etc. and with antibiotics treatment.

Another disease associated with FMOs is hypertension. Especially the results of studies conducted on fish indicate that FMO can have a role in regulating the blood pressure by participating in the metabolism of organic osmolites or substances that take part in regulating the blood pressure. ${ }^{38}$

In the studies where it is argued that there is a correlation between FMO enzymes and diabetes, it has been shown that the hepatic FMO activity in animal models increases in insulin dependent and non-insulin dependent diabetes. In this respect, it has also been reported that increase in FMO activity can be observed in obese or overweight individuals. ${ }^{41,42}$

FMO enzymes are also associated with other diseases such as hemochromatosis, ${ }^{43}$ gastrointestinal system diseases and colon cancer ${ }^{44}$ and it has been reported that there is a significant relation between smoking and FMO enzymes. 22,45

\section{Role of flavin-containing monooxygenases in drug design}

The effect of FMOs on the metabolism of drugs and other xenobiotics are still not clearly defined. Especially in the phase 1 reactions in drug metabolism, CYP450 enzymes have a significant dominance.

The number of FMO mediated drug metabolisms is far less than CYPs, and these enzymes are less stable than CYPs in the lack of $\mathrm{NADPH}$ and at high temperatures. Despite these disadvantages, the fact that FMO is not easily induced and inhibited by environmental chemicals may be essential in terms of drug reactions. On the other hand, the number of adverse drug-drug interactions can be reduced by increasing the contribution of FMO in the drug metabolism. By adding functional groups that are oxidized by FMO to the produced drugs can both decrease the dependency on CYP450 metabolism and reduce the number of adverse drug-drug interactions. Furthermore, while there are specific inhibitors for each CYP450 enzyme, there are only limited number of inhibitors for FMOs, which can pose as an advantage in drug manufacturing. Oxidation metabolism of a specific drug depends on the enzyme activity and relatively on the amount in the tissue or organ in which the metabolism takes place. Moreover, even if the activities of CYP2D6 and FMO3 enzymes against a drug are the same, taking the amounts in the liver into consideration, the contribution of $\mathrm{FMO} 3$ in the metabolism of that drug is considered to be higher. However, under in vivo conditions, it is extremely difficult to determine precisely the contribution of the relative contribution of $\mathrm{FMO}$ to the metabolism of drug. ${ }^{13}$

\section{CONCLUSION}

In recent years, the number of studies on the metabolism of xenobiotics has substantially increased. By revealing the unknown properties of $\mathrm{FMO}$, one of the phase 1 enzymes, more information about the biotransformation of xenobiotics can be obtained. In addition, when compared to CYP450 in terms of drug design, FMO enzymes may provide substantial advantage since they are not easily affected by chemicals, and there are low number of adverse drug-drug interactions due to their genetic polymorphisms and inhibitions.

Conflict of Interest: No conflict of interest was declared by the authors.

\section{REFERENCES}

1. Katzung BG, Basic \& Clinical Pharmacology (9th ed.) NY: Lange Medical Books/McGraw Hill, 2004.

2. Ziegler DM, Mitchell $\mathrm{CH}$. Microsomal oxidase IV: properties of mixedfunction amine oxidase isolated from pig liver microsomes. Arch Biochem Biophys. 1972;150:116-125.

3. Ziegler DM, Poulsen LL. Hepatic microsomal mixed-function amine oxidase. Methods Enzymol. 1978;52:142-151.

4. Tynes RE, Sabourin PJ, Hodgson E. Identifi-cation of distrinct hepatic and pulmonary forms of microsomal flaving-containing monooxyge-nase in the mouse and rabbit. Biochem Biophys Res Commun. 1985;126:1069-1075.

5. Cashman JR, Zhang J. Interindividual diffe-rences of human flavincontaining mono-oxygenase 3: genetic polymorphisms and functional variation. Drug Metab Dispos. 2002;30:1043-1052.

6. Cashman JR. Structural and catalytic properties of the mammalian flavin-containing mono-oxygenase. Chem Res Toxicol. 1995;8:166-181.

7. Testa B, Pedretti A, Vistoli G. Reactions and enzymes in the metabolism of drugs and other xenobiotics. Drug Discov Today. 2012;17:549-560.

8. Cruciani G, Valeri A, Goracci L, Pellegrino RM, Buonerba F, Baroni M. Flavin monooxygenase metabolism: Why medicinal chemists should matter. J Med Chem. 2014;57:6183-6196.

9. Hodgson E, Blake BL, Levi PE, Mailman RB, Lawton MP, Philpot RM, Genter MB, Flavin-containing monooxygenases: substrate specificity and complex metabolic pathways, In Molecular Aspects of Oxidative Drug Metabolizing Enzymes: Their significance in Environmental Toxicology, Chemical Carcinogenesis and Health, Nato ASI Series, pp 225-235, Plenum Publishers, New York. 1995.

10. Poulsen LL, Ziegler DM. Multisubstrate flavin-containing monooxygenases: applications of mechanism to specificity. Chem Biol Interact. 1995;96:57-73.

11. Kousba A, Soll R, Yee S, Martin M. Cyclic conversion of the novel SRC kinase inhibitor [7-(2,6- dichloro-phenyl)-5-methyl-benzo[1,2, 4] triazin-3-yl]-[4-(2-pyrrolidin-1-yl-ethoxy)-phenyl] amine (TG100435) and its $\mathrm{N}$-oxide metabolite by flavin-containing monoxygena-ses and cytochrome P450 reductase. Drug Metab Dispos. 2007;35:2242-2251.

12. Adali O, Carver GC, Philpot RM. Modulation of human flavin containing monooxygenase 3 activity by tricyclic antidepressants and other agents: Importance of residue 428. Arch Biochem Biophys. 1998;358:92-97.

13. Krueger SK, Williams DE. Mammalian flavin-containing monooxygenases: structure function, genetic polymorphisms and role in drug metabolism. Pharmacol Ther. 2005;106:357-387. 
14. Hines RN, Hopp KA, Franco J, Saeian K, Begun FP. Alternative processing of the human FMO6 gene renders transcripts incapable of encoding a functional flavin-containing monooxygenase. Mol Pharmacol. 2002;62:320-325.

15. Motika MS, Zhang J, Cashman JR. Flavin-containing monooxygenase 3 and human disease. Expert Opin Drug Metab Toxicol. 2007;3:831-845.

16. Hodgson E, Cherrington NJ, Philpot RM, Rose RL, Biochemical aspects of flavin-containing monooxygenases (FMOs), In Molecular and Applied Aspects of Oxidative Drug Metabolizing Enzymes, Nato ASI Series, pp 55-70, Plenum Publishers, New York. 1999.

17. Ziegler DM. Flavin-containing mono-oxygenase: Catalytic mechanisms and substrate specificities. Drug Metab Rev. 1988;19:1-32.

18. Hernandez D, Janmohamed A, Chandan P, Phillips IR, Shephard EA. Organization and evolution of the flavin-containing mono-oxygenase genes of human and mouse identification of novel gene and pseudogene clusters. Pharmacogenetics. 2004;14:117-130.

19. Lawton MP, Cashman JR, Cresteil T, Dolphin CT, Elfarra AA, Hines RN, Hodgson E, Kimura T, Ozols J, Phillips IR, et al. A nomenclature of the mammalian flavin-containing monooxygenase gene family based on amino acid sequence identities. Arch Biochem Biophys. 1994;308:254257.

20. Shephard EA, Dolphin CT, Fox MF, Povey S, Smith R, Phillips IR. Localization of genes encoding three distinct flavin-containing monooxygenases to human chromosome 1q. Genomics. 1993;16:85-89.

21. McCombie RR, Dolphin CT, Povey S, Phillips IR, Shephard EA. Localization of human flavin-containing monooxygenase genes FMO2 and FMO5 to chromosome 1q. Genomics. 1996;34:426-429.

22. Cashman JR, Zhang J. Human flavin-containing monooxygenases. Annu Rev Pharmacol Toxicol. 2006;46:65-100.

23. Larsen BK, Schlenk D. Effect of salinity of flavin-containing monooxygenase expression and activity in rainbow trout (Oncorhynchus mykiss). J Comp Physiol B 2001;171:421-429.

24. Zhang J, Cashman JR. Quantitative analysis of FMO gene mRNA levels in human tissues. Drug Metab Dispos. 2006;34:19-26.

25. Krueger SK, Williams DE, Yueh MF, Martin SR, Hines RN, Raucy JL, Dolphin CT, Shephard EA, Phillips IR. Genetic polymorphism of flavincontaining mono-oxygenase (FMO). Drug Metab Rev. 2002;34:523-532.

26. Bhamre S, Ravindranath V. Presence of flavin-containing monooxygenase in rat brain. Biochem Pharmacol. 1991;42:442-444.

27. Shehin-Johnson SE, Williams DE, Larsen-Su S, Stresser DM, Hines RN. Tissue-specific expres-sion of flavin-containing monooxygenase (FMO) forms 1 and 2 in the rabbit. J Pharmacol Exp Ther. 1995;272:1293-1299.

28. Bhamre S, Bhagwat SV, Shankar SK, Boyd MR, Ravindranath V. Flavincontaining monooxygenase mediated metabolism of psychoactive drugs by human brain microsomes. Brain Res. 1995;672:276-280.

29. Bhamre S, Bhagwat SV, Shankar SK, Boyd MR, Ravindranath V. Flavincontaining monooxygenase mediated metabolism of benzyamide in perfused brain and liver. Brain Res. 1995;672:276-280.

30. Williams DE, Hale SE, Muerhoff AS, Masters BS. Rabbit lung flavincontaining monooxygenase. Purification and induction during pregnancy. Mol Pharmacol. 1985;28:381-390.
31. Janmohamed A, Dolphin CT, Phillips IR, Shephard EA. Quantification and cellular localization of expression in human skin of genes encoding flavin-containing mono-oxygenases and cytochromes P450. Biochem Pharmacol. 2001;62:777-786.

32. Falls JG, Ryu DY, Cao Y, Levi PE, Hodgson E. Regulation of mouse liver flavin-containing monooxygenases 1 and 3 by sex steroids. Arch Biochem Biophys. 1997;342:212.

33. Coecke S, Debast G, Phillips IR, Vercruysse A, Shephard EA, Rogiers V. Hormonal regulation of microsomal flavin-containing mono-oxygenase activity by sex steroids and growth hormone in co-cultured adult male rat hepatocytes. Biochem Pharmacol. 1998;56:1047-1051.

34. Cashman JR, Lattard V, Lin J. Effect of total parenteral nutrition and choline on hepatic flavin-containing and cytochrome P450 monooxygenase activity in rats. Drug Metab Dispos. 2004;32:222-229.

35. Borbas T, Benko B, Dalmadi B, Szabo I, Tihanyi K. Insulin in flavincontaining monooxygenase regulation: Flavin-containing monooxygenase and cytochrome P450 activities in experimental diabetes. Eur J Pharm Sci. 2006;28:51-58.

36. Cashman JR, Zhang J. Human flavin-containing monooxygenase: quantification in human tissues. Toxicologist. 2005;84:1554.

37. Koukouritaki SB, Poch MT, Cabacungan ET, McCarver DG, Hines RN. Discovery of novel flavin-containing monooxygenase 3 (FMO3) single nucleotide polymorphisms and functional analysis of upstream haplotype variants. Mol Pharmacol. 2005;68:383-392.

38. Cashman JR, Camp K, Fakharzadeh SS, Fennessey PV, Hines RN, Mamer OA, Mitchell SC, Nguyen GP, Schlenk D, Smith RL, Tjoa SS, Williams $D E$, Yannicelli S. Biochemical and clinical aspects of the human flavincontaining monooxygenase form 3 (FMO3) related to trimethylaminuria. Curr Drug Metab. 2003;4:151-170.

39. Zhang $A Q$, Mitchell SC, Smith RL. Exacerbation of symptoms of fishodour syndrome during menstruation. Lancet. 1996;348:1740-1741.

40. Knodell RG, Steele NM, Cerra FB, Gross JB, Solomon TE. Effects of parenteral and enteral hyperalimentation on hepatic drug metabolism in the rat. J Pharmacol Exp Ther. 1984;229:589-597.

41. Rouer E, Rouet P, Delpech M, Leroux JP. Purification and comparison of liver microsomal flavin-containing monooxygenase from normal and streptozotocin diabetics rats. Biochem Pharmacol. 1988;37:3455-3459.

42. Ko JH, Lee TJ, Park CS, Jang EH, Oh YM, Kang JH. Enhanced activity of flavin-containing monooxygenase in human subjects with high body mass index and in obese mice fed a high fat diet. Mol Cell Toxicol. 2008;4:5-10.

43. Muckenthaler M, Roy CN, Custodio AO, Miñana B, deGraaf J, Montross LK, Andrews NC, Hentze MW. Regulatory defects in liver and intestine implicate abnormal hepcidin and Cybrd1 expression in mouse hemochromatosis. Nat Genet. 2003;34:102-107.

44. Hisamuddin IM, Wehbi MA, Chao A, Wyre HW, Hylind LM, Giardiello FM, Yang VW. Genetic polymorphism of human flavin-containing monooxygenase 3 in sulindac mediated primary chemoprevention of familial adenomatous polyposis. Clin Cancer Res. 2004;10:8357-8362.

45. Cholerton S, Ayesh R, Idle JR, Smith RL. The pre-eminence of nicotine $\mathrm{N}$-oxidation and its diminution after carbamizole administration. British J Clin Pharmacol. 1988;26:652-653. 